\title{
Trust, confidence, and equity affect the legitimacy of natural resource governance
}

\author{
$\underline{\text { Rachel A. Turner }}^{1}, \underline{\text { Jane Addison }}^{2}, \underline{\text { Adrian Arias }}^{3}$, Brock J. Bergseth $^{3}$, Nadine A. Marshall $^{2,4}, \underline{\text { Tiffany H. Morrison }}^{3}$ and $_{\text {Renae C. }}$
} $\underline{\text { Tobin }}^{4,5}$

\begin{abstract}
Social-ecological systems are often highly complex, making effective governance a considerable challenge. In large, heterogeneous systems, hierarchical institutional regimes may be efficient, but effective management outcomes are dependent on stakeholder support. This support is shaped by perceptions of legitimacy, which risks being undermined where resource users are not engaged in decision-making. Although legitimacy is demonstrably critical for effective governance, less is known about the factors contributing to stakeholders' perceptions of legitimacy or how these perceptions are socially differentiated. We quantitatively assessed stakeholder perceptions of legitimacy (indicated by support for rules) and their contributory factors among 307 commercial fishers and tourism operators in Australia's Great Barrier Reef Marine Park. Legitimacy was most strongly associated with trust in information from governing bodies, followed by confidence in institutional performance and the equity of management outcomes. Legitimacy differed both within and among resource user groups, which emphasizes the heterogeneous nature of commonly defined stakeholder groups. Overall, tourism operators perceived higher legitimacy than did commercial fishers, which was associated with higher trust in information from management agencies. For fishers, higher levels of trust were associated with: (1) engagement in fisheries that had high subsector cohesion and positive previous experiences of interactions with governing bodies; (2) location in areas with greater proximity to sources of knowledge, resources, and decision-making; and (3) engagement in a Reef Guardian program. These findings highlight the necessity of strategies and processes to build trust among all user groups in large social-ecological systems such as the Great Barrier Reef Marine Park. Furthermore, the social differentiation of perceptions that were observed within user groups underscores the importance of targeted strategies to engage groups that may not be heard through traditional governance channels.
\end{abstract}

Key Words: fisheries; Great Barrier Reef; justice; marine conservation; tourism; trust

\section{INTRODUCTION}

Protected areas are increasingly being implemented in efforts to achieve conservation goals, yet many fail to deliver the expected socioeconomic and environmental outcomes, often due to ineffective governance (Hughes 2011). Studies of long-enduring institutions for natural resource governance provide insights into the characteristics that contribute to success. These characteristics include small resource systems, homogeneous resource users, and locally devised rules (Ostrom 1990, Agrawal 2001). A shift to localized and inclusive institutions for governing resource use is therefore increasingly promoted, and expected benefits include increased democracy and accountability (Armitage et al. 2007, Berkes 2007, Cinner et al. 2012). While achieving positive effects in many cases, this shift is not a panacea for improving conservation outcomes (Evans et al. 2011, Gutiérrez et al. 2011, Cinner et al. 2012). Numerous difficulties remain, including successful engagement with heterogeneous communities and the development of effective fiscal, administrative, and democratic structures of responsibility and accountability, particularly in communities with limited capacity (Lane et al. 2004).

Improving natural resource governance may be particularly challenging in large, complex social-ecological systems. Design principles for managing common-pool resources have primarily been derived from studies of small-scale, self-organizing, or community-based systems (Armitage et al. 2009). These principles may not apply as well in complex social-ecological systems that are large, such as those that span multiple catchments and contain significant resource user populations, or that are heterogeneous in terms of resource regimes and resource user diversity (Ostrom 2009). In such complex systems, where opportunities for collective rule-making by resource users may be limited or transaction costs may be high, governance structures can be both hierarchical and polycentric (Duit and Galaz 2008, Morrison 2014). At this larger scale, governance weaknesses can be amplified, especially if exclusion of resource users from decision-making means that poor support for management measures undermines legitimacy (Lane 2001, Schultz et al. 2011). Understanding the legitimacy of governance systems perceived by resource users in complex social-ecological systems is therefore critical for engendering support of, and compliance with, management measures (Sutinen and Kuperan 1999, Arias 2015).

Legitimacy can be defined as the right of a governing body to rule and the recognition of this right among those being governed (Tyler 2006). Thus, legitimacy is derived from normative beliefs about who is entitled to rule, and how (Lockwood 2010). These beliefs are shaped by the structure and processes that define the governing body and are related to factors such as effectiveness, transparency, and inclusiveness (Levi et al. 2009, Scharpf 2009, Schmidt 2013). Insights from global environmental governance theory suggest that legitimate authority can be granted through the shared acceptance of an institutional regime among those governed (Bernstein 2004, Habermas 2010). Where legitimacy is not elicited through formal democratic processes, it can be earned through demonstrated commitment, integrity, and effectiveness

${ }^{1}$ Environment and Sustainability Institute, University of Exeter, ${ }^{2}$ Commonwealth Scientific and Industrial Research Organisation (CSIRO), Land and Water, ${ }^{3}$ Australian Research Council Centre of Excellence for Coral Reef Studies, James Cook University, ${ }^{4}$ College of Science and Engineering, James Cook University, ${ }^{5}$ Centre for Sustainable Tropical Fisheries and Aquaculture, James Cook University 
in producing outcomes (Lockwood 2010). Research in criminology and psychology has demonstrated the importance of legitimacy for enhancing compliance with rules, which makes governance easier and more effective (Tyler 2006, 2010, Levi et al. 2009). To date, the factors that influence legitimacy are not well understood. Their inclusion in analyses of environmental governance, however, promises insights useful for developing more effective natural resource management strategies.

Researchers have distinguished between value-based and behavioral legitimacy (e.g., Levi et al. 2009). Value-based legitimacy refers to a willingness to obey rules, which can be legitimized through congruence with social norms and values (Bernstein 2004). Value-based legitimacy in turn may lead to a manifestation of these values through compliance, termed behavioral legitimacy. Factors contributing to value-based legitimacy include the trustworthiness of a governing body, and procedural and distributive justice (Levi et al. 2009, Hard et al. 2012; Fig. 1). Trustworthiness is determined by public perceptions of the performance and competence of the governing body. Trust therefore reflects the degree of confidence and goodwill directed toward governing institutions (Lai et al. 2010) and the information they share with stakeholders (Gilmour et al. 2015). Trust has also proven to be vital for eliciting compliance in settings as diverse as the workplace (Kim and Mauborgne 1993), community-based management and comanagement of natural resources (Pretty 2003, Armitage et al. 2009), and tax compliance (Scholz and Lubell 1998). Hence, we view trust as a key precondition of legitimacy within environmental governance contexts.

Fig. 1. Conceptual framework illustrating preconditions for legitimacy (adapted from Levi et al. 2009). Dashed box indicates components not included in this study.

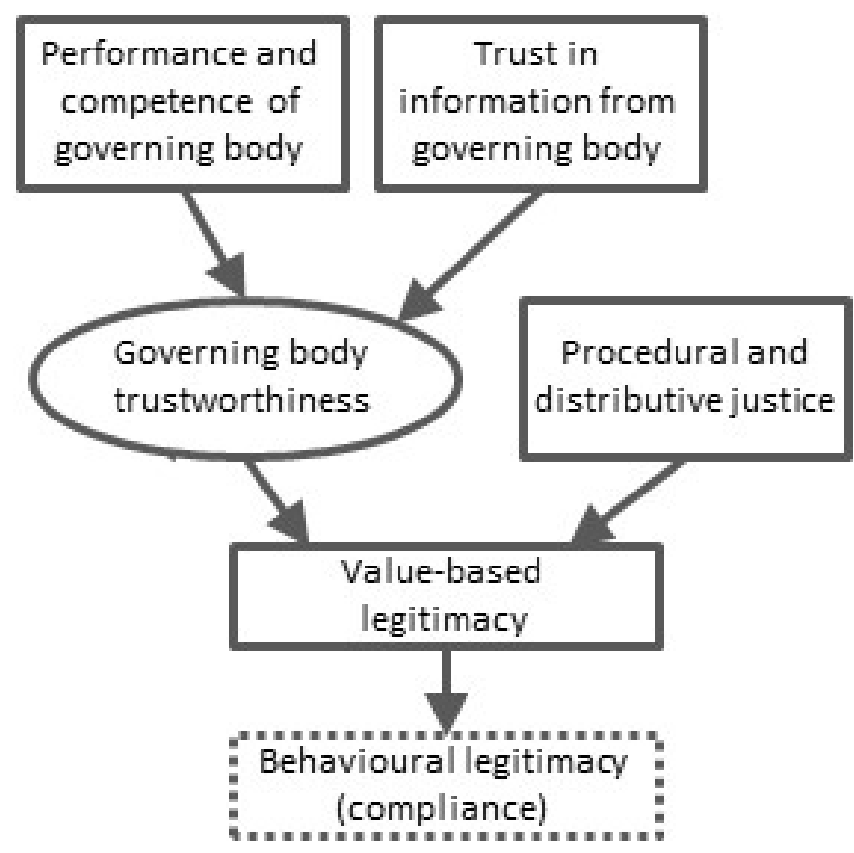

Justice is another important precondition for legitimacy. Procedural justice, or procedural fairness, is a measure of how well a governing body enforces regulations and applies them equally to all. Legitimacy may be undermined if enforcement is perceived to be discriminatory, even if the rules are socially acceptable (Birnbaum 2016). Governing bodies can adhere to principles of distributive justice by considering the distribution of costs and benefits arising from management decisions, the claims of different groups, and providing justification or compensation when inequitable outcomes occur (Lockwood 2010). Legitimacy may be weakened if these principles are not evident. The link between justice and voluntary cooperation and compliance has been demonstrated in numerous studies and social dilemma experiments (De Cremer 2003, De Cremer and Tyler 2005).

While the importance of legitimacy has been studied in a range of contexts, there remains limited understanding of the relative importance of factors that contribute to legitimacy, particularly in large, complex, natural resource governance systems. An improved understanding of factors such as trust and justice is important given the potential role of legitimacy in engendering voluntary compliance (Hønneland 1999, Shaw 2005). Furthermore, though perceptions of management measures and governance quality differ according to socio-demographic attributes and in different contexts (McClanahan et al. 2005a, Gelcich et al. 2009, Pita et al. 2010, Turner et al. 2014), few empirical studies of natural resource governance have explored how perceptions of legitimacy are socially differentiated within an institutional regime. This is a key research gap in complex social-ecological systems, where resource user groups are large and heterogeneous.

In this study, we investigate factors contributing to the legitimacy of the institutional regime for managing Australia's Great Barrier Reef Marine Park (GBRMP). The Great Barrier Reef (GBR) is a complex social-ecological system and has the largest and most diverse coral reef ecosystem on Earth. The GBRMP encompasses multiple resource users, including local residents, commercial fishers, tourism operators, and tourists (Marshall et al. 2016). In this context, the current conceptualization of institutional design principles may have limited utility, given the large and heterogeneous group of resource users and the complex institutional regime with multiple layers and boundaries (Evans et al. 2014). The GBRMP is primarily governed by a single statutory body, the Great Barrier Reef Marine Park Authority (GBRMPA), and governance can be considered hierarchical (Day and Dobbs 2013). Understanding resource user perceptions that relate to legitimacy of this institutional regime are key to improving institutional fit and management success in this context.

The GBRMP is used as a case study to explore the factors contributing to legitimacy among key direct resource users in the region: tourism operators and commercial fishers. These stakeholder groups represent important industries whose influence shapes policy and management (Olsson et al. 2008, Macintosh et al. 2010). Our specific objectives were: (1) to assess perceived legitimacy, indicated by the level of support for the rules of the GBRMP by these two direct resource user groups; (2) to assess factors contributing to legitimacy; and (3) to identify the 
characteristics of users who perceive weak legitimacy. This knowledge can help in designing institutional regimes that can engender greater legitimacy and support among resource users.

\section{METHODS}

\section{Great Barrier Reef Marine Park}

The GBRMP is located on the largest coral reef system in the world, which spans $>2000 \mathrm{~km}$ along Australia's northeastern coast. As an environment of outstanding cultural and natural value, it was declared a World Heritage Site in 1981. Most of the World Heritage Site is encompassed within the multiple-use GBRMP designated in 1975, which uses an extensive zoning system to manage human activities (Day 2002). The latest rezoning process was implemented in 2004 and reflected broad environmental goals held by GBRMPA, including support for long-term interests such as fishing, tourism, and conservation. Although the rezoning is considered a successful example of protected area planning (Day and Dobbs 2013), it also created tensions between and within resource user groups (Macintosh et al. 2010)

Tourism is the largest economic use of the GBRMP, generating approximately AUD\$5.2 billion to the national economy and > 64,000 full-time jobs (Deloitte Access Economics 2013). Tourism is mostly nature based, relying on the reputation of the Great Barrier Reef as a unique and spectacular place that provides opportunities for diving, snorkelling, sailing, and recreational fishing. GBRMPA plays a regulatory role in tourism, for example, levying an environmental management charge and developing zoning, permits, and guidelines.

Various types of fishing are permitted in $>60 \%$ of the GBRMP. Commercial fishing activities comprise line, trawl, net, pot, and harvest fisheries, which together contribute approximately AUD\$122.9 million to the national economy and generate approximately 700 full-time jobs (Deloitte Access Economics 2013). Commercial fishers are typically highly dependent on fishing for their household income and have been in the industry for much of their working lives (Lédée et al. 2012). The rezoning process encountered strong opposition from the commercial and recreational fishing sectors, leading to a significant structural adjustment package to compensate fishers (Macintosh et al. 2010).

The GBRMP, like many large-scale protected areas, was established under a hierarchical governance tradition but is increasingly seeking to generate voluntary support among users. The institutional regime is complex and multilayered, with federal, state, and local agencies involved in various aspects of management (Day and Dobbs 2013). Although this formally constitutes a polycentric governance system, it has been described as highly centralized because most resource users are not directly involved in decision-making (Evans et al. 2014). Power is concentrated in the hands of a small number of management actors through a unifying agency and overarching legislation (GBRMP Act of 1975). However, GBRMPA governance includes comanagement arrangements with indigenous groups (Olsson et al. 2008, Nursey-Bray and Rist 2009). Recent efforts have also been directed toward inclusion of commercial stakeholders through schemes such as the Reef Guardian program, which encourages voluntary adoption of environmental standards by commercial users (e.g., fishers measure carbon emissions, report on reef health, and use modified gear to reduce environmental impacts; GBRMPA, Reef guardian fishers: http://www.gbrmpa. gov.au/our-partners/reef-guardians/reef-guardian-fishers). While noteworthy, most governance decisions are still made by the GBRMPA, and the importance of engendering voluntary compliance in this context is recognized (GBRMPA 2014). This situation highlights the need to develop and maintain arrangements that engender legitimacy and support among resource users. The GBRMP thus provides an ideal opportunity to explore the role of legitimacy in the context of a wellestablished, hierarchical governance arrangement for a large and complex system.

\section{Data collection}

A social and ecological long-term monitoring program was established in 2011 to explore the status of different user groups and their interactions with the GBRMP. The program was funded by the National Environmental Research Program and led by the Commonwealth Scientific and Industrial Research Organisation. Questions were designed in collaboration with research and management agencies as well as stakeholder representatives to elicit perceptions, values, experiences, and attitudes relating to the reef and its management. Our study uses data from two telephone surveys conducted in 2013 targeting key resource user groups: commercial fishers and tourism operators. Databases of contacts were built using publicly available data, personal contacts, and unpublished data (Marshall et al. 2016). A total of 611 commercial fishers and 213 tourism operators were identified via access to license databases for commercial fishers and internet searches for active tourism operators. A total of 329 interviews were conducted ( 210 commercial fishers, 119 tourism operators), representing an estimated $34 \%$ of commercial fishers and $56 \%$ of tourism operators in the GBR region.

Comparable questions were included in both surveys. Drawing on a conceptual framework (Fig. 1), we included four questions relating to legitimacy. The first question was designed to elicit respondents' support for current rules and regulations in the GBRMP as an indicator of value-based legitimacy. We assume that support for rules is one indicator of social acceptance of the institutional regime and contributes to a willingness or sense of obligation to comply. This in turn is expected to contribute to behavioral legitimacy, or compliance, which was not measured here. Three further questions assessed factors considered to be preconditions for legitimacy: (1) confidence in the performance of governing institutions, (2) trust in information received from the GBRMPA, and (3) perceived fairness of access to GBR resources (Table 1). We assume that the first two factors reflect the trustworthiness of governing institutions, and the third factor reflects distributive justice (Fig. 1). Responses to all questions were measured using a 10-point ordinal scale reflecting agreement with specific statements (see Table 1). Such scales are commonly used to derive comparable data on perceptions across large populations (Bennett 2016) and were considered appropriate here given the scale of the GBRMP area. Further data were collected on respondent characteristics such as demographics, reef-use practices, location, dependence on reef-related income, and engagement with the GBRMPA. 
Table 1. Dependent and explanatory variables derived from survey question statements. Responses to all question statements were measured using a 10 -point ordinal scale $(1=$ very strongly disagree, $10=$ very strongly agree $)$.

\begin{tabular}{|c|c|c|}
\hline Variable & Indicator measured & Survey question statement \\
\hline Value-based legitimacy & Support for management measures & $\begin{array}{l}\text { "I support the current rules and regulations that affect access and } \\
\text { use of the Great Barrier Reef (GBR)" }\end{array}$ \\
\hline \multirow{3}{*}{$\begin{array}{l}\text { Factors contributing to } \\
\text { legitimacy }\end{array}$} & Governing body performance & "I feel confident the GBR is well managed" \\
\hline & $\begin{array}{l}\text { Trust in information from management } \\
\text { agencies }\end{array}$ & $\begin{array}{l}\text { "I trust the information I receive about the GBR from the Great } \\
\text { Barrier Marine Park Authority" }\end{array}$ \\
\hline & Distributive justice & $\begin{array}{l}\text { "I do not have fair access to the GBR compared to other user } \\
\text { groups" } \dagger\end{array}$ \\
\hline
\end{tabular}

$\dagger$ Scores for this question were reversed in analysis to derive a positively oriented scale comparable to other variables.

\section{Data analysis}

Support for rules and regulations within both user groups was examined by visually comparing plots of responses using the Likert package in R (Bryer and Speerschneider 2013). A statistical modelling approach using a cumulative link model with a logit link was then used to investigate the relationship between the three factors expected to contribute to legitimacy and value-based legitimacy indicated by support for management measures. User type (commercial fisher or tourism operator) was also included in the initial model. Because of some nonresponses to survey questions relating to support for management measures $(N=4)$, governing body performance $(N=5)$, trust in information from the GBRMPA $(N=6)$, and distributive justice $(N=14)$, the model used a total of 307 complete records (195 commercial fishers, 112 tourism operators).

Finally, based on results of the initial analysis, we identified trust in information from the GBRMPA to be an aspect of legitimacy that was particularly weak and variable among commercial fishers (Fig. 2). Thus, a cumulative link model with a logit link was used to investigate the characteristics of commercial fishers among whom trust in information from the GBRMPA was low. Characteristics investigated included those relating to demographics, fishing practices, location, economic dependence on fishing, and engagement in management activities (see Table A1.1 in Appendix 1). Variability in trust among tourism operators was not explored further because of their comparatively positive and homogeneous responses.

\section{RESULTS}

\section{Support for rules and regulations}

In total, $50 \%$ of respondents agreed (score of 6-10) that they supported the rules and regulations in the GBRMP. The level of support for rules and regulations differed between the two user groups, with tourism operators more commonly expressing higher levels of support than commercial fishers (Fig. 2). Responses of fishers were more negative and varied across positive and negative scores $($ median $=5$, interquartile range $=2-7$ ) than were those of tourism operators $($ median $=8$, interquartile range $=5-9$ ).

Tourism operators more commonly expressed agreement with all three statements reflecting factors contributing to legitimacy (Fig. 2). The majority of both user groups believed that access to the GBR was equitable, with $82 \%$ of tourism operators and $59 \%$ of commercial fishers agreeing that they had fair access to the GBR in comparison to other user groups. Confidence in the management of the GBR was weaker than the belief of fair access to the GBR, with $65 \%$ of tourism operators and $46 \%$ of commercial fishers agreeing that they were confident that the GBRMP is well managed. The largest difference in user group perceptions was in relation to trust in the information received from the GBRMPA, with $82 \%$ of tourism operators agreeing that they trusted information received from the GBRMPA compared to $29 \%$ of commercial fishers. One-third of fishers $(34 \%)$ chose the category representing the strongest possible disagreement with this latter statement (score of 1).

\section{Legitimacy and its contributory factors}

Stepwise removal of explanatory variables to refine the ordinal regression model resulted in a final model retaining three explanatory variables, all of which had a positive effect on legitimacy (Table A1.2 in Appendix 1). Despite differences in legitimacy between commercial fishers and tourism operators (Fig. 2), perceptions of trust in information from the GBRMPA, governing body performance, and distributive justice were important predictors of legitimacy. Once these predictors were accounted for, user type was not a statistically significant explanatory variable and was removed from the model.

Trust in information received from the GBRMPA exhibited the greatest effect size, followed by governing body performance and distributive justice (Table A1.2 in Appendix 1). The odds ratio indicates the odds of a unit increase or decrease in the explanatory variable being associated with a higher or lower value of the dependent variable. For example, for a one-unit increase in trust in information from the GBRMPA, the combined odds of the middle and high levels of support for rules and regulations (i.e., scores of 2-9) is 33 times greater than the lowest level (i.e., score of 1), given that other variables in the model are held constant.

\section{Trust among commercial fishers}

Given the important role of trust in information from the GBRMPA in predicting legitimacy and the lack of trust identified among commercial fishers, we examined the characteristics of fishers that were associated with greater levels of trust. Stepwise removal of explanatory variables to refine the ordinal regression model resulted in a final model retaining three characteristics of fishers as explanatory variables: main fishery, natural resource management area of their home port, and reported participation in the Reef Guardian program (Table A1.3 in Appendix 1).

Differences in the natural resource management area of fishers' home ports showed some of the highest effect sizes. Fishers in the 
Fig. 2. Support for rules and regulations and indicators of perceived legitimacy by two key user groups of the Great Barrier Reef Marine Park. Shading represents the proportion of respondents choosing each score on a 10point ordinal scale $(1=$ very strongly disagree, $10=$ very strongly agree $)$. GBR $=$ Great Barrier Reef, GBRMPA $=$ Great Barrier Marine Park Authority.

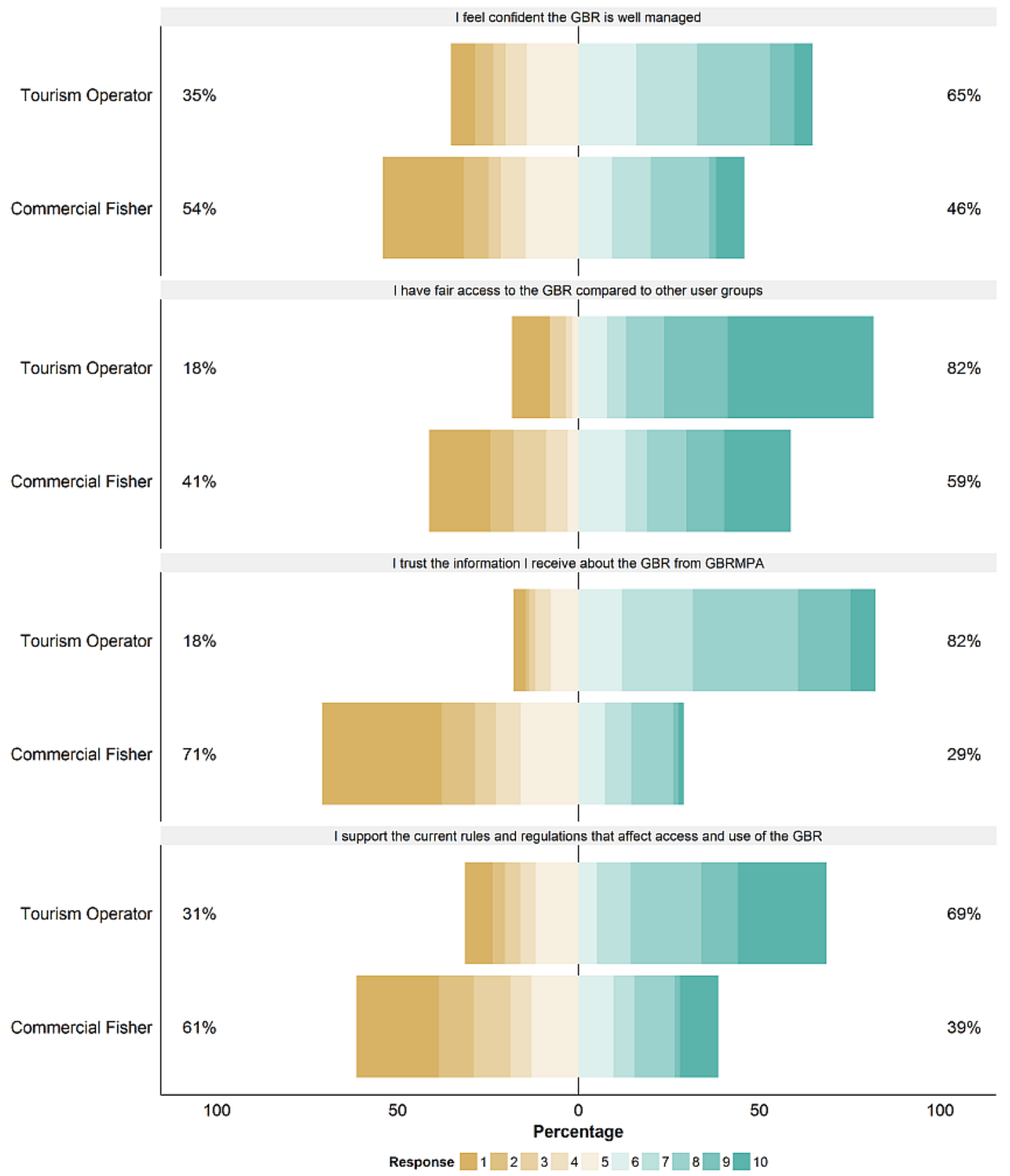

areas of Burdekin and Interstate were more likely to report trust in management agencies, whereas in the areas of Cape York and Burnett-Mary, only $12 \%$ and $15 \%$ of fishers, respectively, agreed that they trusted information received from the GBRMPA (Fig. 3). For main fishery type, greater trust in information from the GBRMPA was reported in particular among fishers in the harvest sector, with comparatively lower trust among those mainly engaged in line, net, pot, or trawl fishing (Fig. 3). Reported participation in the Reef Guardian program was associated with greater levels of trust in information from GBRMPA (Fig. 3). 
Fig. 3. Perceptions of trust in information from the Great Barrier Marine Park Authority (GBRMPA) among commercial fishers in relation to characteristics of respondents. (A) Main gear type. (B) Participation in the Reef Guardian program. (C) Home port natural resource management area. Shading represents the proportion of respondents choosing each score on a 10-point ordinal scale ( 1 = very strongly disagree, $10=$ very strongly agree). GBR = Great Barrier Reef.

(A)

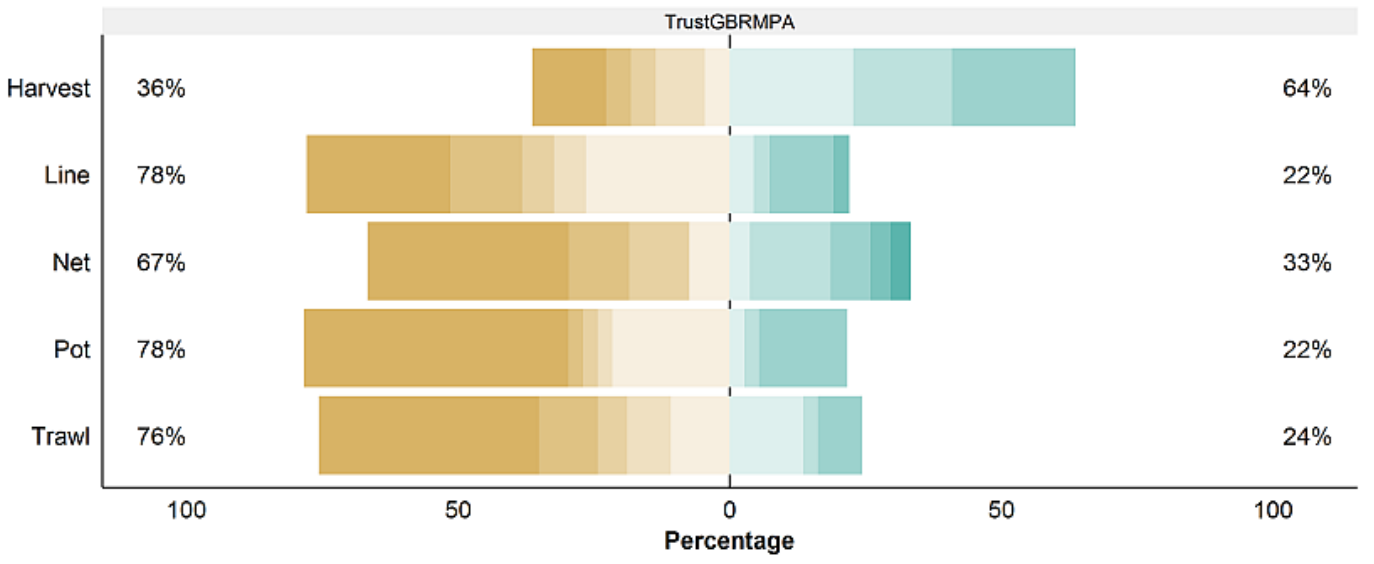

(B)

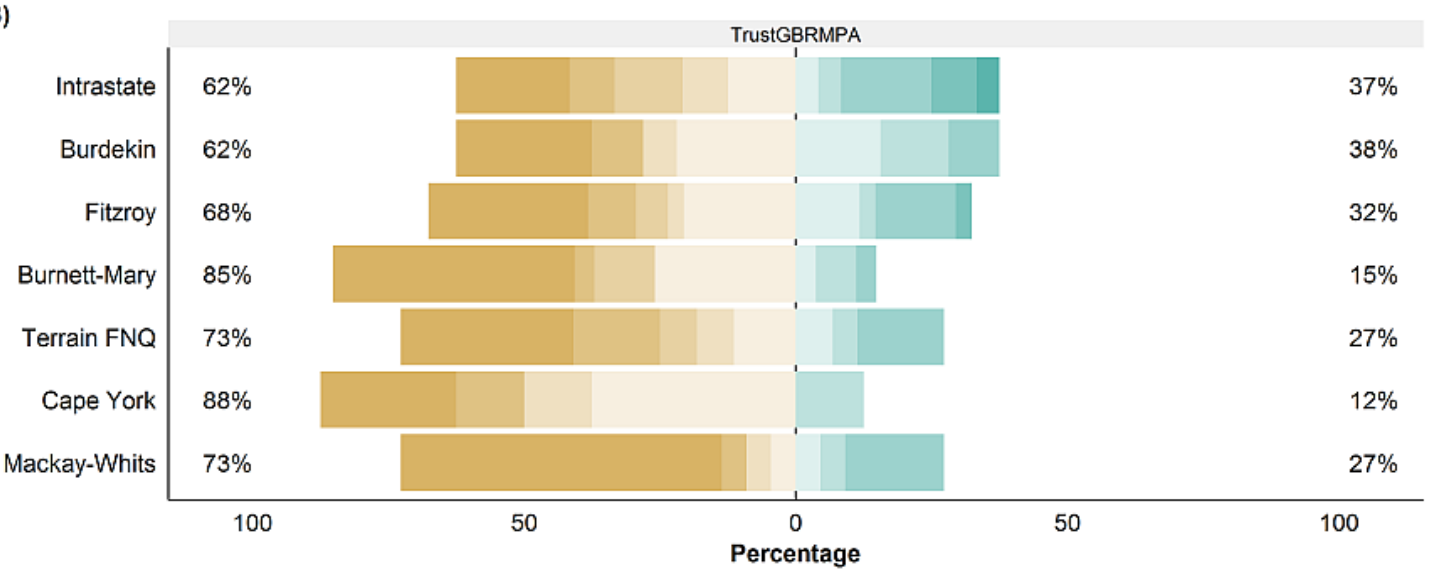

(C)

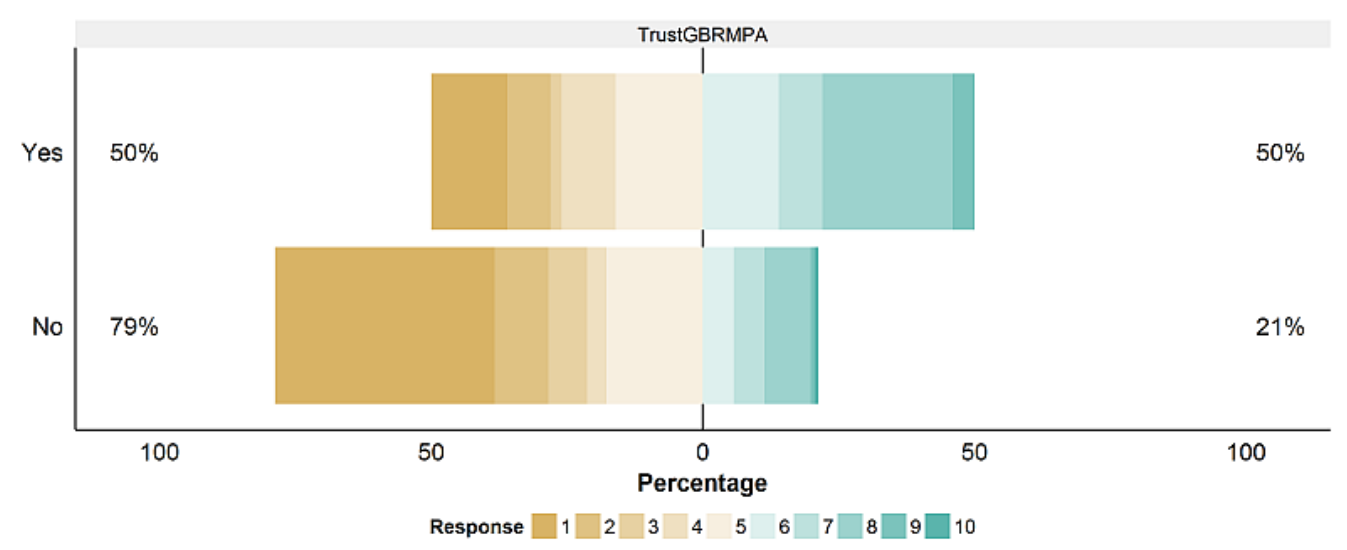

\section{DISCUSSION}

\section{Predictors of legitimacy}

Our findings demonstrate the relative importance of factors contributing to legitimacy of natural resource governance in a complex social-ecological system. Consistent with frameworks describing the preconditions for legitimacy, trust in information received, perceived competence of governing bodies, and perceived fairness were all important predictors of legitimacy. Trust in information from the GBRMPA was particularly important, affirming research that describes positive relationships 
between citizens' perceptions of government trustworthiness and their acceptance of government authority (Scholz and Lubell 1998, Stern 2008, Levi et al. 2009). In a natural resource management context, trust in information from different sources has been identified as a key influence in determining the types of knowledge that are incorporated into stakeholders' decisionmaking processes (Gilmour et al. 2015). Trust is also widely recognized as critical to successful comanagement of natural resources because it helps build effective collaborative relationships and minimizes transaction costs (Pretty 2003, Armitage et al. 2007).

Perceived legitimacy also increased with greater confidence in governing body performance. This confidence can reflect not only resource users' appraisals that institutions are motivated to serve those governed, but also that the institutions will deliver on their promises (Levi et al. 2012). Resource users' recognition of authorities' commitment, efforts, and integrity in working toward their objectives can enhance earned legitimacy (Lockwood 2010). Confidence in governing institutions has also been linked to voluntary compliance (Cook et al. 2005), which is critical for effective natural resource management and conservation (Arias 2015).

Though procedural and distributive justice are increasingly recognized as critical aspects of legitimate management (Lockwood 2010, Hard et al. 2012), our results indicate that distributive justice was the least influential of the three indicators. The positive influence of fairness on legitimacy is consistent with frameworks highlighting principles of effective governance for natural resources (Graham et al. 2003, Lockwood 2010). However, the greater effect of trust in our model in comparison to justice may result from the close relationship between these two concepts (Tyler 2010), which we chose to treat as distinct aspects of the institutional regime in accordance with other recent studies (Tyler and Huo 2002, Levi et al. 2009). Alternatively, in complex social-ecological systems it may be difficult for individuals to determine whether distributional justice has occurred; accordingly, the importance of trust in a governing body may be given more weight.

\section{Differing levels of legitimacy among resource user groups}

Differing perceptions of the legitimacy of the GBRMP institutional regime between and within user groups is consistent with previous studies of resource user perceptions of management and governance (McClanahan et al. 2005b, Gelcich et al. 2009, Velez et al. 2014). Higher support and greater homogeneity of responses among tourism operators compared to fishers may indicate that the values of tourism operators are more aligned with the perspectives of conservation-minded natural resource managers (Hoelting et al. 2013). Tourism operators' activities are largely nonextractive and are unlikely to be affected negatively by zoning arrangements that prohibit various fishing activities. In addition, in large-scale systems where direct participation of all stakeholders is less feasible than in smaller systems, organized interests may be better represented in governance systems (Suškevičs 2012). Tourism operators may be more centrally located, organized, and easier to contact than fishers, resulting in greater potential for interaction with governing institutions and opportunities to build trust. For example, the GBRMPA issues permits directly to tourism operators and maintains regular contact through collection of passenger levies.
In contrast, fishers are often poorly organized and represented. For example, the primary representative group, the Queensland Seafood Industry Association (covering the GBR, southeast Queensland, and the Gulf of Carpentaria) had 231 members at the time of our survey, although there were $>560$ active fishing businesses in the GBR alone (Tobin et al. 2014). Furthermore, administration of commercial fishers takes place primarily through state fisheries agencies rather than through the GBRMPA. Commercial fishers are also often driven by a strong sense of individualism and have disparate goals and values (Marshall 2007, Pita et al. 2013), which can make engagement in governance more difficult. Lack of trust in the GBRMPA may also be associated with many commercial fishers' perception that they were treated unfairly during the last GBRMP rezoning process (Lédée et al. 2012).

\section{Differing levels of trust among fishers}

Heterogeneity in the perceptions of commercial fishers was exemplified in the diversity of responses surrounding trust in information from the GBRMPA. Trust was differentiated strongly by main fishery type, reflecting the likely formation of cohesive groups within resource user sectors as a result of their shared working history and experience. It is common for cohesive groups to form based on common types of fishing undertaken (Crona and Bodin 2006). The harvest fishery, a small subsector dominated by the marine aquarium supply industry, stood out from the other subsectors as having high levels of trust in information from the GBRMPA. This group has a history of working together proactively, demonstrated by their development of a climate change vulnerability assessment (Donnelly 2011) and a stewardship action plan (Donnelly 2013), both of which were produced in partnership with research and management organizations. Experience of positive collaboration between fishers and management agencies is likely to lead to higher levels of trust between different actors (Davenport et al. 2007, de Vos and van Tatenhove 2011).

After accounting for main fishery type, trust among fishers was also differentiated by region. Regions with higher trust (Burdekin, Fitzroy, Far North Queensland, and Mackay-Whitsunday) tended to have greater access to research and learning centers, as well as to GBRMPA offices, than did those with lower levels of trust (i.e., Cape York and Burnett-Mary). The Burdekin region exhibited the highest levels of trust and also contains the GBRMPA head office. In contrast, the Cape York region, which reported the lowest levels of trust, does not have a GBRMPA office and is remote from centers of power. Thus, these results may be explained by the increased opportunities for positive interactions with governing bodies afforded by proximity to an organizational office (Davenport et al. 2007, de Vos and van Tatenhove 2011). The presence of centers conducting relevant research may also increase the perceived relevance of information provided by management agencies, thereby enhancing institutional capacity to engender trust in the quality of information (Robins and Dovers 2007). Finally, the Burdekin region also differed from other regions in that it was the only region to develop successfully a comanagement committee, the Burdekin Sustainable Fisheries Alliance (GBRMPA 2011).

Fishers who reported participation in the Reef Guardian program also reported higher trust in information received from the GBRMPA than did nonparticipants, irrespective of their main 
fishery type and region. Engagement in this program may improve relationships between fishers and the GBRMPA through interactions that build trust. However, it is uncertain if the Reef Guardian program recruited fishers who were already engaged and proactive in environmental stewardship, and if so, what the benefits might be for developing relationships between the GBRMPA and the broader fishing community. Interestingly, more fishers reported participation in the scheme than are formally involved (17 were officially listed as Reef Guardians at the time of survey, yet 52 survey respondents claimed to be involved; Tobin et al. 2014). This finding might suggest that: (1) there was confusion about what the program was, (2) fishers consider themselves reef stewards even if they are not formally involved in the program (Tobin et al. 2014), or (3) there was a social desirability bias leading fishers to report falsely participation in the program. Nevertheless, the significant effect of this variable in predicting legitimacy suggests that fishers reporting to be part of the Reef Guardian program did have a higher sense of legitimacy than those who did not.

\section{Limitations of the research}

Perceptions of legitimacy among resource users may be shaped by factors not explicitly considered in our conceptual framework. The survey method that we used was appropriate for identifying broad stakeholder perceptions and exploring how these might influence governance. Future studies, however, would benefit from qualitative research in the form of detailed in-depth interviews and focus groups aimed specifically at understanding the wide range of variables that affect stakeholder beliefs and attitudes toward governance. For example, good governance principles such as accountability and inclusiveness reflect people's opportunities to engage with governance systems and can influence whether people endorse institutional regimes (Lockwood 2010). However, many elements of good governance are interrelated and were reflected in the findings through the characteristics and perceptions of different resource user groups.

The data used to reflect components of the conceptual framework may also have influenced our findings. We used support for rules and regulations as a measure of value-based legitimacy, which refers to a sense of willingness or obligation to comply with rules (Levi et al. 2009). However, willingness to comply may exist even where support for rules is lacking. If individuals perceive governing bodies to be competent and fair, they may feel obliged to comply with rules that they do not support or by which they are negatively affected. For example, Barents Sea fishers complained about specific regulations but expressed a moral commitment to comply based on positive perceptions about inclusion of their views, representation, and fair enforcement (Hønneland 2000). Such viewpoints would reflect a form of legitimacy that would not be captured here. Value-based legitimacy may therefore be higher than our findings suggest.

Our analysis did not include the behavioral legitimacy component of the conceptual framework that we drew upon; thus, we cannot empirically explore the extent to which value-based legitimacy might influence compliance with rules. Though legitimacy is likely to be an important factor influencing decisions about compliance, this relationship is not necessarily linear (Arias et al. 2015). For example, where acceptability of rules is low, compliance may be high because of a fear of sanctions (Birnbaum 2016).
Furthermore, resource users may exhibit stewardship over natural resources, even if they do not support regulations. For example, fishers in the GBR held positive attitudes toward marine conservation, but support for the rezoning plan was lacking because of perceptions relating to inadequate engagement in the process and negative effects on their businesses (Lédée et al. 2012). To understand better the implications of differing perceptions of legitimacy for natural resource management, future research should further consider how value-based legitimacy may influence voluntary compliance and stewardship.

\section{CONCLUSIONS}

Our study underlines two key implications for effective natural resource management. First, the findings demonstrate the particular importance of trust as a prerequisite for legitimacy in a large, complex, social-ecological system. High levels of trust in governing bodies are crucial in determining stakeholders' perceived legitimacy of management decisions, which, if high, may increase voluntary compliance and decrease transactional costs associated with cooperation between different actors (Pretty 2003). Natural resource governance should therefore be conducted in a manner that fosters trust between stakeholders and managers (Scharpf 2009, Schmidt 2013), yet trust and legitimacy are created and manifested differently in different governance systems. In large social-ecological systems that are not conducive to resource users being closely connected or interacting often with governing bodies, deliberate strategies may be particularly important for building trust.

Second, social differentiation of trust in the GBRMPA highlights a need for strategies targeted toward particular groups and contexts to build trust. Our results highlight the heterogeneous nature of commercial fishers, who are often considered in engagement strategies as a single homogeneous group. Governing bodies may need to devise strategies targeted toward groups around which fishers organize or coalesce such as fishery type or region. Further attempts to understand and increase stakeholder perceptions of legitimacy in natural resource governance will also benefit from systematic and periodic monitoring of legitimacy indicators such as trust, as this enables managers to detect changes in specific areas or stakeholder groups (Cundill and Fabricius 2010, Turner et al. 2014). This process may be particularly critical in hierarchical or polycentric governance arrangements in which resource managers may interact infrequently with resource users. Overall, higher levels of trust seem to be correlated with subsector cohesion, positive previous experiences, and proximity to sources of knowledge, resources, and decision-making. While governing bodies can manipulate access to decision-making and distance to power (e.g., through public participation and setting up regional offices in remote regions) to enhance trust and legitimacy, many of these correlates are deeply historical and cannot be engineered quickly or undertaken in a tokenistic fashion (Putnam et al. 1993, Morrison 2007). Genuine efforts to develop trust will require continued interaction and commitment (Armitage et al. 2009).

Although there is continued demand for improved governance of protected areas, the factors that contribute to increased legitimacy in large, complex systems are not well understood. Our study provides insights on natural resource governance by identifying the relative importance of these factors in the GBRMP. Our findings confirm that trust, justice, and governance competence 
are common ingredients for both small- and large-scale socialecological systems, yet the characteristics of large and complex systems may exacerbate the challenges of achieving these preconditions for legitimacy, particularly where resource users are numerous and diverse. Our study demonstrates heterogeneous perceptions of resource users in the GBR context, which complicates engagement and governance strategies that view user groups as homogeneous entities. Although hierarchical institutional regimes may facilitate efficiency and control to achieve positive environmental outcomes (Evans et al. 2014), it may be more difficult to enable participation and build trust in these settings. Where resource user perceptions of legitimacy are low, institutional regimes should consider targeted engagement efforts and perhaps greater institutional diversity. Accordingly, metagovernance strategies could be used to shape institutional regimes in ways that establish conditions enabling meaningful engagement with numerous and diverse stakeholder groups (Morrison 2014). Such strategies can establish the broader governance conditions that foster networked self-organization, social capital, and the self-regulation of industries, and potentially enable a shift away from utilitarian consultation methods and toward a path of more genuine participation and stewardship.

Responses to this article can be read online at: http://www.ecologyandsociety.org/issues/responses. php/8542

\section{Acknowledgments:}

The Social and Ecological Long Term Monitoring Program (SELTMP) for the Great Barrier Reef Marine Park was established in 2011 with funding provided by the Australian Government under the National Environment Research Program (NERP). We thank the SELTMP team for their support and collaboration. We also sincerely thank the commercial fishers and tourism operators that were part of this research and the interviewers that were involved. The arguments presented here are the sole responsibility of the authors. This paper was developed in a workshop funded by the Julius Career Award, the Commonwealth Scientific and Industrial Research Organisation (CSIRO), and the Environment and Sustainability theme of the University of Exeter's Humanities and Social Science Strategy. The authors acknowledge additional support from the University of Exeter's Outward Mobility Fund (R. T.), the Australian Research Council (T. M., A. A., B. J. B. ), CSIRO (J. A.), and AusAID (A. A.).

\section{LITERATURE CITED}

Agrawal, A. 2001. Common property institutions and sustainable governance of resources. World Development 29(10):1649-1672. http://dx.doi.org/10.1016/s0305-750x(01)00063-8

Arias, A. 2015. Understanding and managing compliance in the nature conservation context. Journal of Environmental Management 153:134-143. http://dx.doi.org/10.1016/j. jenvman.2015.02.013

Arias, A., J. E. Cinner, R. E. Jones, and R. L. Pressey. 2015. Levels and drivers of fishers' compliance with marine protected areas.
Ecology and Society 20(4):19. http://dx.doi.org/10.5751/ ES-07999-200419

Armitage, D., F. Berkes, and N. Doubleday, editors. 2007. Adaptive co-management: collaboration, learning, and multi-level governance. UBC Press, Vancouver, Canada.

Armitage, D. R., R. Plummer, F. Berkes, R. I. Arthur, A. T. Charles, I. J. Davidson-Hunt, A. P. Diduck, N. C. Doubleday, D. S. Johnson, M. Marschke, P. McConney, E. W. Pinkerton, and E. K. Wollenberg. 2009. Adaptive co-management for socialecological complexity. Frontiers in Ecology and the Environment 7(2):95-102. http://dx.doi.org/10.1890/070089

Bennett, N. J. 2016. Using perceptions as evidence to improve conservation and environmental management. 30(3):582-592. http://dx.doi.org/10.1111/cobi.12681

Berkes, F. 2007. Community-based conservation in a globalized world. Proceedings of the National Academy of Sciences 104 (39):15188-15193. http://dx.doi.org/10.1073/pnas.0702098104

Bernstein, S. 2004. Legitimacy in global environmental governance. Journal of International Law and International Relations 1(1-2):139-166. [online] URL: $\underline{\text { htp://www.jilir.org/docs/ }}$ issues/volume 1/1 10 BERNSTEIN FINAL.pdf

Birnbaum, S. 2016. Environmental co-governance, legitimacy, and the quest for compliance: When and why is stakeholder participation desirable? Journal of Environmental Policy and Planning 18(3):306-323. http://dx.doi.org/10.1080/1523908X.20$\underline{15.1077440}$

Bryer, J., and K. Speerschneider. 2013. Likert: functions to analyze and visualize Likert type items. CRAN R project. [online] URL: http://cran.r-project.org/package=likert

Cinner, J. E., T. R. McClanahan, M. A. MacNeil, N. A. J. Graham, T. M. Daw, A. Mukminin, D. A. Feary, A. L. Rabearisoa, A. Wamukota, N. Jiddawi, S. J. Campbell, A. H. Baird, F. A. Januchowski-Hartley, S. Hamed, R. Lahari, T. Morove, and J. Kuange. 2012. Comanagement of coral reef social-ecological systems. Proceedings of the National Academy of Sciences 109 (14):5219-5222. http://dx.doi.org/10.1073/pnas.1121215109

Cook, K. S., R. Hardin, and M. Levi. 2005. Cooperation without trust? Russell Sage Foundation, New York, New York, USA.

Crona, B., and Ö. Bodin. 2006. What you know is who you know? Communication patterns among resource users as a prerequisite for co-management. Ecology and Society 11(2): 7. [online] URL: http://www.ecologyandsociety.org/vol11/iss2/art7/

Cundill, G., and C. Fabricius. 2010. Monitoring the governance dimension of natural resource co-management. Ecology and Society 15(1): 15. [online] URL: http://www.ecologyandsociety. org/vol15/iss1/art15/

Davenport, M. A., J. E. Leahy, D. H. Anderson, and P. J. Jakes. 2007. Building trust in natural resource management within local communities: a case study of the Midewin National Tallgrass Prairie. Environmental Management 39(3):353-368. http://dx.doi. org/10.1007/s00267-006-0016-1

Day, J. C. 2002. Zoning-lessons from the Great Barrier Reef Marine Park. Ocean and Coastal Management 45(2-3):139-156. http://dx.doi.org/10.1016/s0964-5691(02)00052-2 
Day, J. C., and K. Dobbs. 2013. Effective governance of a large and complex cross-jurisdictional marine protected area: Australia's Great Barrier Reef. Marine Policy 41:14-24. http://dx. doi.org/10.1016/j.marpol.2012.12.020

De Cremer, D. 2003. Why inconsistent leadership is regarded as procedurally unfair: the importance of social self-esteem concerns. European Journal of Social Psychology 33(4):535-550. http://dx.doi.org/10.1002/ejsp.162

De Cremer, D., and T. R. Tyler. 2005. Managing group behavior: the interplay between procedural justice, sense of self, and cooperation. Advances in Experimental Social Psychology 37:151-218. http://dx.doi.org/10.1016/S0065-2601(05)37003-1

de Vos, B. I., and J. P. M. van Tatenhove. 2011. Trust relationships between fishers and government: new challenges for the comanagement arrangements in the Dutch flatfish industry. Marine Policy 35(2):218-225. http://dx.doi.org/10.1016/j.marpol.2010.10.002

Deloitte Access Economics. 2013. Economic contribution of the Great Barrier Reef. Great Barrier Reef Marine Park Authority, Townsville, Australia. [online] URL: https://www.environment. gov.au/sustainability/publications/economic-contribution-great-barrierreef-march-2013

Donnelly, R. 2011. Climate change vulnerability assessment: Queensland marine aquarium supply industry, 2010. Research Publication 108. Great Barrier Reef Marine Park Authority, Townsville, Australia. [online] URL: http://elibrary.gbrmpa.gov. au/jspui/bitstream/11017/476/1/Climate-change-vulnerability-assessmentQueensland-marine-aquarium-supply-industry-2010.pdf

Donnelly, R. J. 2013. Stewardship action plan 2013: mitigating ecological risk in a changing climate. Pro-vision Reef, Cairns, Australia. [online] URL: http://www.provisionreef.org.au/wpcontent/uploads/2013/08/SAP_II-7-8-2013-web.pdf

Duit, A., and V. Galaz. 2008. Governance and complexityemerging issues for governance theory. Governance 21(3):311-335. http://dx.doi.org/10.1111/j.1468-0491.2008.00402.x

Evans, L. S., N. C. Ban, M. Schoon, and M. Nenadovic. 2014. Keeping the 'Great' in the Great Barrier Reef: large-scale governance of the Great Barrier Reef Marine Park. International Journal of the Commons 8(2):396-427. http://dx.doi.org/10.18352/ ijc. 405

Evans, L., N. Cherrett, and D. Pemsl. 2011. Assessing the impact of fisheries co-management interventions in developing countries: a meta-analysis. Journal of Environmental Management 92(8):1938-1949. http://dx.doi.org/10.1016/j.jenvman.2011.03.010

GBRMPA (Great Barrier Reef Marine Park Authority). 2011. Information sheet: for commercial net fishermen about netting changes in the Bowling Green Bay Species Conservation (Dugong Protection) Special Management Area. Australian Government, Great Barrier Reef Marine Park Authority, Townsville, Australia. [online] URL: http://www.gbrmpa.gov.au/ data/assets/ pdf file/0003/13386/gbrmpa BowlingGreenBayRegulationChange_InfoSheet_Dec2011.pdf

GBRMPA (Great Barrier Reef Marine Park Authority). 2014. Great Barrier Reef outlook report 2014. Great Barrier Reef Marine Park Authority, Townsville, Australia. [online] URL: http://www. gbr.qld.gov.au/documents/gbr-outlook-report-2014-full.pdf
Gelcich, S., N. Godoy, and J. C. Castilla. 2009. Artisanal fishers' perceptions regarding coastal co-management policies in Chile and their potentials to scale-up marine biodiversity conservation. Ocean and Coastal Management 52(8):424-432. http://dx.doi. org/10.1016/j.ocecoaman.2009.07.005

Gilmour, P., B. Coffey, and K. O’Toole. 2015. Trust and knowledge exchange in coastal settings. Australian Journal of Maritime and Ocean Affairs 7(1):66-74. http://dx.doi. org/10.1080/18366503.2015.1014013

Graham, J., B. Amos, and T. Plumptre. 2003. Governance principles for protected areas in the 21st century. Institute on Governance, Ottawa, Canada. [online] URL: http://iog.cal publications/governance-principles-for-protected-areas-in-the-21stcentury/

Gutiérrez, N. L., R. Hilborn, and O. Defeo. 2011. Leadership, social capital and incentives promote successful fisheries. Nature 470(7334):386-389. http://dx.doi.org/10.1038/nature09689

Habermas, J. 2010. A political constitution for the pluralist world society? Pages 267-288 in G. W. Brown and D. Held, editors. The cosmopolitanism reader. Polity Press, Malden, Massachusetts, USA.

Hard, C. H., K. R. Hoelting, P. Christie, and R. B. Pollnac. 2012. Collaboration, legitimacy, and awareness in Puget Sound MPAs. Coastal Management 40(3):312-326. http://dx.doi. org/10.1080/08920753.2012.677640

Hoelting, K. R., C. H. Hard, P. Christie, and R. B. Pollnac. 2013. Factors affecting support for Puget Sound Marine Protected Areas. Fisheries Research 144:48-59. http://dx.doi.org/10.1016/j. fishres.2012.10.006

Hønneland, G. 1999. A model of compliance in fisheries: theoretical foundations and practical application. Ocean and Coastal Management 42(8):699-716. http://dx.doi.org/10.1016/ $\underline{\text { S0964-5691(99)00041-1 }}$

Hønneland, G. 2000. Compliance in the Barents Sea fisheries. How fishermen account for conformity with rules. Marine Policy 24(1):11-19. http://dx.doi.org/10.1016/S0308-597X(98)00058-X

Hughes, T. 2011. The future of marine governance. Solutions 2 (1). [online] URL: http://www.thesolutionsjournal.com/node/868

Kim, W. C., and R. A. Mauborgne. 1993. Procedural justice, attitudes, and subsidiary top management compliance with multinationals' corporate strategic decisions. Academy of Management Journal 36(3):502-526. http://dx.doi.org/10.2307/256590

Lai, Y.-L., L. Cao, and J. S. Zhao. 2010. The impact of political entity on confidence in legal authorities: a comparison between China and Taiwan. Journal of Criminal Justice 38(5):934-941. http://dx.doi.org/10.1016/j.jcrimjus.2010.06.010

Lane, M. B. 2001. Affirming new directions in planning theory: comanagement of protected areas. Society and Natural Resources 14(8):657-671. http://dx.doi.org/10.1080/08941920118212

Lane, M. B., G. T. McDonald, and T. H. Morrison. 2004. Decentralisation and environmental management in Australia: a comment on the prescriptions of the Wentworth Group. Australian Geographical Studies 42(1):103-115. http://dx.doi. org/10.1111/j.1467-8470.2004.00246.x 
Lédée, E. J. I., S. G. Sutton, R. C. Tobin, and D. M. De Freitas. 2012. Responses and adaptation strategies of commercial and charter fishers to zoning changes in the Great Barrier Reef Marine Park. Marine Policy 36(1):226-234. http://dx.doi.org/10.1016/j. marpol.2011.05.009

Levi, M., A. Sacks, and T. Tyler. 2009. Conceptualizing legitimacy, measuring legitimating beliefs. American Behavioral Scientist 53(3):354-375. http://dx.doi.org/10.1177/0002764209338797

Levi, M., T. Tyler, and A. Sacks. 2012. The reasons for compliance with law. Pages 70-99 in R. Goodman, D. Jinks, and A. K. Woods, editors. Understanding social action, promoting human rights. Oxford University Press, Oxford, UK. http://dx.doi.org/10.1093/ acprof:oso/9780195371895.003.0004

Lockwood, M. 2010. Good governance for terrestrial protected areas: a framework, principles and performance outcomes. Journal of Environmental Management 91(3):754-766. http://dx. doi.org/10.1016/j.jenvman.2009.10.005

Macintosh, A., T. Bonyhady, and D. Wilkinson. 2010. Dealing with interests displaced by marine protected areas: a case study on the Great Barrier Reef Marine Park Structural Adjustment Package. Ocean and Coastal Management 53(9):581-588. http:// dx.doi.org/10.1016/j.ocecoaman.2010.06.012

Marshall, N. A. 2007. Can policy perception influence social resilience to policy change? Fisheries Research 86(2-3):216-227. http://dx.doi.org/10.1016/j.fishres.2007.06.008

Marshall, N. A., E. Bohensky, M. Curnock, J. Goldberg, M. Gooch, B. Nicotra, P. Pert, L. M. Scherl, S. Stone-Jovicich, and R. C. Tobin. 2016. Advances in monitoring the human dimension of natural resource systems: a showcase from the Great Barrier Reef. Environmental Research Letters, in press.

McClanahan, T., J. Davies, and J. Maina. 2005a. Factors influencing resource users and managers' perceptions towards marine protected area management in Kenya. Environmental Conservation 32(1):42-49. http://dx.doi.org/10.1017/S0376892904001791

McClanahan, T. R., J. Maina, and J. Davies. 2005b. Perceptions of resource users and managers towards fisheries management options in Kenyan coral reefs. Fisheries Management and Ecology 12(2):105-112. http://dx.doi.org/10.1111/j.1365-2400.2004.00431. $\underline{\mathrm{X}}$

Morrison, T. H. 2007. Multiscalar governance and regional environmental management in Australia. Space and Polity 11 (3):227-241. http://dx.doi.org/10.1080/13562570701811551

Morrison, T. H. 2014. Developing a regional governance index: the institutional potential of rural regions. Journal of Rural Studies 35:101-111. http://dx.doi.org/10.1016/j.jrurstud.2014.04.004

Nursey-Bray, M., and P. Rist. 2009. Co-management and protected area management: achieving effective management of a contested site, lessons from the Great Barrier Reef World Heritage Area (GBRWHA). Marine Policy 33(1):118-127. http:// dx.doi.org/10.1016/j.marpol.2008.05.002

Olsson, P., C. Folke, and T. P. Hughes. 2008. Navigating the transition to ecosystem-based management of the Great Barrier Reef, Australia. Proceedings of the National Academy of Sciences 105(28):9489-9494. http://dx.doi.org/10.1073/pnas.0706905105
Ostrom, E. 1990. Governing the commons: the evolution of institutions for collective action. Cambridge University Press, Cambridge, UK.

Ostrom, E. 2009. A general framework for analyzing sustainability of social-ecological systems. Science 325 (5939):419-422. http://dx.doi.org/10.1126/science.1172133

Pita, C., G. J. Pierce, and I. Theodossiou. 2010. Stakeholders' participation in the fisheries management decision-making process: fishers' perceptions of participation. Marine Policy 34 (5):1093-1102. http://dx.doi.org/10.1016/j.marpol.2010.03.009

Pita, C., I. Theodossiou, and G. J. Pierce. 2013. The perceptions of Scottish inshore fishers about marine protected areas. Marine Policy 37:254-263. http://dx.doi.org/10.1016/j.marpol.2012.05.007

Pretty, J. 2003. Social capital and the collective management of resources. Science 302(5652):1912-1914. http://dx.doi.org/10.1126/ science. 1090847

Putnam, R. D., R. Leonardi, and R. Nonetti. 1993. Making democracy work: civic traditions in modern Italy. Princeton University Press, Princeton, New Jersey, USA.

Robins, L., and S. Dovers. 2007. NRM regions in Australia: the "haves" and the "have nots". Geographical Research 45 (3):273-290. http://dx.doi.org/10.1111/j.1745-5871.2007.00460.x

Scharpf, F. W. 2009. Legitimacy in the multilevel European polity. European Political Science Review 1(2):173-204. http://dx.doi. org/10.1017/s1755773909000204

Schmidt, V. A. 2013. Democracy and legitimacy in the European Union revisited: input, output and "throughput." Political Studies 61(1):2-22. http://dx.doi.org/10.1111/j.1467-9248.2012.00962.x

Scholz, J. T., and M. Lubell. 1998. Trust and taxpaying: testing the heuristic approach to collective action. American Journal of Political Science 42(2):398-417. http://dx.doi.org/10.2307/2991764

Schultz, L., A. Duit, and C. Folke. 2011. Participation, adaptive co-management, and management performance in the world network of biosphere reserves. World Development 39(4):662-671. http://dx.doi.org/10.1016/j.worlddev.2010.09.014

Shaw, R. L. 2005. Enforcement and compliance in the Northeast groundfish fishery: perceptions of procedural justice in fishery management, the effects of regulatory methods, and prospects for compliance. Dissertation. University of Rhode Island, Kingston, Rhode Island, USA. [online] URL: http://digitalcommons.uri. edu/dissertations/AAI3206256

Stern, M. J. 2008. Coercion, voluntary compliance and protest: the role of trust and legitimacy in combating local opposition to protected areas. Environmental Conservation 35(3):200-210. http://dx.doi.org/10.1017/s037689290800502x

Suškevičs, M. 2012. Legitimacy analysis of multi-level governance of biodiversity: evidence from 11 case studies across the EU. Environmental Policy and Governance 22(4):217-237. http://dx. doi.org/10.1002/eet.1588

Sutinen, J. G., and K. Kuperan. 1999. A socio-economic theory of regulatory compliance. International Journal of Social Economics 26(1/2/3):174-193. http://dx.doi.org/10.1108/03068299910229569 
Tobin, R., E. Bohensky, M. Curnock, J. Goldberg, M. Gooch, N. Marshall, B. Nicotra, P. Pert, L. Scherl, and S. Stone-Jovicich. 2014. The social and economic long term monitoring program (SELTMP) 2014: commercial fishing in the Great Barrier Reef. Technical report. National Environmental Research Program. Reef and Rainforest Research Centre, Cairns, Australia. [online] URL: http://www.nerptropical.edu.au/sites/default/files/publications/ files/NERP-TE-PROJ-10.1-SELTMP-2014-COMMECIAL-FISHINGComplete.pdf

Turner, R. A., C. Fitzsimmons, J. Forster, R. Mahon, A. Peterson, and S. M. Stead. 2014. Measuring good governance for complex ecosystems: perceptions of coral reef-dependent communities in the Caribbean. Global Environmental Change 29:105-117. http:// dx.doi.org/10.1016/j.gloenvcha.2014.08.004

Tyler, T. R. 2006. Psychological perspectives on legitimacy and legitimation. Annual Review of Psychology 57:375-400. http://dx. doi.org/10.1146/annurev.psych.57.102904.190038

Tyler, T. R. 2010. Why people cooperate: the role of social motivations. Princeton University Press, Princeton, New Jersey, USA. http://dx.doi.org/10.1515/9781400836666

Tyler, T. R., and Y. J. Huo. 2002. Trust in the law: encouraging public cooperation with the police and courts. Russel Sage Foundation, New York, New York, USA.

Velez, M., S. Adlerstein, and J. Wondolleck. 2014. Fishers' perceptions, facilitating factors and challenges of communitybased no-take zones in the Sian Ka'an Biosphere Reserve, Quintana Roo, Mexico. Marine Policy 45:171-181. http://dx.doi. org/10.1016/j.marpol.2013.12.003 
Appendix 1. Supplementary material

Table A1.1. Characteristics of commercial fishers measured in the survey

\begin{tabular}{|c|c|c|c|}
\hline Fisher characteristic & Indicator measured & Description & Data type \\
\hline \multicolumn{4}{|l|}{ Demographics } \\
\hline & Age & Age of fisher & Interval \\
\hline & Education & Respondent has university or other higher education & Categorical $(\mathrm{Y} / \mathrm{N})$ \\
\hline & Family & Whether family members are involved in fishing & Categorical $(\mathrm{Y} / \mathrm{N})$ \\
\hline \multicolumn{4}{|l|}{ Fishing practices } \\
\hline & Employees & Number of employees & Interval \\
\hline & Owner/operator & Licence owner, operator, or owner-operator & Categorical \\
\hline & Years fishing & Number of years fishing experience & Interval \\
\hline & Days fishing & Number of days fishing in past 12 months & Interval \\
\hline & Distance travelled & Typical distance travelled from home port & Categorical \\
\hline & Multiple ports & Whether respondent uses multiple ports & Categorical (Y/N) \\
\hline & Fishery types & Number of different fisheries involved in & Interval \\
\hline & Main fishery & Main fishery the respondent is involved in & $\begin{array}{l}\text { Categorical (Line, Net, } \\
\text { Pot, Trawl, Harvest) }\end{array}$ \\
\hline & Multiple vessels & Whether respondent operates multiple vessels & Categorical $(\mathrm{Y} / \mathrm{N})$ \\
\hline Location & Home port NRM & $\begin{array}{l}\text { Natural Resource Management (NRM) area in which } \\
\text { respondents home port is located }\end{array}$ & Categorical \\
\hline \multicolumn{4}{|c|}{. } \\
\hline & Fishing income & Proportion of household income from fishing & Interval \\
\hline & GBR income & Proportion of fishing income derived from the GBR & Interval \\
\hline \multicolumn{4}{|l|}{ Engagement } \\
\hline & Research & Respondent is involved in research or management & Categorical $(\mathrm{Y} / \mathrm{N})$ \\
\hline & Reef Guardian & Participant in GBRMPA's Reef Guardian programme & Categorical (Y/N) \\
\hline
\end{tabular}

Table A1.2. Cumulative link model estimates of resource users' $(n=307)$ perceived legitimacy and retained explanatory variables. Log likelihood: - 571.44, condition number of Hessian: 180

\begin{tabular}{lrrrrrrr}
\hline Explanatory variable & Estimate & SE & z value & $\operatorname{Pr}(>|z|)$ & \multicolumn{1}{c}{$\begin{array}{l}\text { Odds } \\
\text { ratio }\end{array}$} & $\begin{array}{r}\text { 95\% CI } \\
\text { (lower) }\end{array}$ & $\begin{array}{r}\text { 95\% CI } \\
\text { (upper) }\end{array}$ \\
\hline Governing body performance & 2.873 & 0.495 & 5.801 & $<0.001$ & 17.698 & 6.703 & 46.724 \\
Distributive justice & 1.122 & 0.355 & -3.161 & 0.002 & 3.071 & 1.532 & 6.158 \\
Trust in information from management agencies & 3.504 & 0.540 & 6.489 & $<0.001$ & 33.242 & 11.535 & 95.792 \\
\hline
\end{tabular}


Table A1.3. Cumulative link model estimates of fishers' $(n=191)$ trust in information from GBRMPA and retained explanatory variables reflecting respondent characteristics. Log likelihood: -348.44, condition number of Hessian: 1.6e+03, AIC: 736.88

\begin{tabular}{|c|c|c|c|c|c|c|c|c|}
\hline Explanatory variable & Category & Estimate & SE & $\mathrm{z}$ value & $\operatorname{Pr}(>|z|)$ & $\begin{array}{l}\text { Odds } \\
\text { ratio }\end{array}$ & $\begin{array}{l}95 \% \text { CI } \\
\text { (lower) }\end{array}$ & $\begin{array}{l}95 \% \text { CI } \\
\text { (upper) }\end{array}$ \\
\hline \multicolumn{9}{|l|}{ Main fishery } \\
\hline & Pot & 0.075 & 0.450 & 0.166 & 0.868 & 1.08 & 0.45 & 2.60 \\
\hline & Net & 0.612 & 0.484 & 1.266 & 0.206 & 1.84 & 0.71 & 4.76 \\
\hline & Line & 0.981 & 0.418 & 2.349 & 0.019 & 2.67 & 1.18 & 6.04 \\
\hline & Harvest & 1.754 & 0.532 & 3.296 & $<0.001$ & 5.78 & 2.04 & 16.40 \\
\hline \multicolumn{9}{|l|}{ Home port NRM area } \\
\hline & Cape York & 0.571 & 0.763 & 0.748 & 0.455 & 1.77 & 0.40 & 7.90 \\
\hline & Terrain FNQ & 0.577 & 0.527 & 1.096 & 0.273 & 1.78 & 0.63 & 5.00 \\
\hline & Burnett-Mary & 0.853 & 0.607 & 1.405 & 0.160 & 2.35 & 0.71 & 7.72 \\
\hline & Fitzroy & 0.988 & 0.548 & 1.804 & 0.071 & 2.69 & 0.92 & 7.86 \\
\hline & Burdekin & 1.587 & 0.561 & 2.827 & 0.005 & 4.89 & 1.63 & 14.70 \\
\hline & Intrastate & 1.938 & 0.617 & 3.138 & 0.002 & 6.94 & 2.07 & 23.29 \\
\hline \multicolumn{8}{|l|}{ Reef Guardian } & 7.15 \\
\hline
\end{tabular}

